\title{
Oncogenic herpesvirus DNA absence in kidney cell lines established from the northern leopard frog Rana pipiens
}

\author{
John W. Williams III ${ }^{1, *}$, Kenyon S. Tweedell ${ }^{2}$, Doreen Sterling ${ }^{1}$, Nikki Marshall ${ }^{1}$, \\ Carolyn G. Christ ${ }^{3}$, Debra L. Carlson ${ }^{4}$, Robert G. McKinnell ${ }^{3}$ \\ ${ }^{1}$ Department of Biology, Tuskegee University, Tuskegee, Alabama 36088, USA \\ ${ }^{2}$ Department of Biology, University of Notre Dame, Notre Dame, Indiana 46556, USA \\ ${ }^{3}$ Department of Genetics and Cell Biology, University of Minnesota, Saint Paul, Minnesota 55108-1095, USA \\ 'Department of Biology, Augustana College, Sioux Falls, South Dakota 57197, USA
}

\begin{abstract}
The etiological agent of the Lucke renal adenocarcinoma of the northern leopard frog Rana pipiens is the Lucké tumor herpesvirus (LTV). LTV can be detected with the electron microscope in thin sections of spontaneous tumors from frogs that have been exposed to a cold environment. No viruses can be detected with the electron microscope in spontaneous tumors of frogs maintained under warm conditions even though the 'virus-free' (warm) tumors contain latent LTV. Because electron microscopy is an insufficient procedure to detect the oncogenic herpesvirus during its latent phase and because we sought to ascertain whether the virus is present in cells which do not manifest electron microscope-detectable viruses, we developed a polymerase chain reaction (PCR) procedure to amplify a Hind III fragment of the viral DNA, JH12. While all warm, 'virus-free', spontaneous kidney tumors studied thus far contain this restriction enzyme fragment of LTV DNA, we report here that we failed to detect JH12 DNA in the tumor-derived cell line PNKT-4B. A normal frog cell line, WMPA, similarly failed to exhibit the restriction enzyme fragment of LTV DNA.
\end{abstract}

KEY WORDS: Rana pipiens - Lucké renal adenocarcinoma - PNKT-4B cell line WMPA cell line . Herpesvirus · Polymerase chain reaction

\section{INTRODUCTION}

The Lucké renal adenocarcinoma afflicts some populations of the northern leopard frog Rana pipiens. The neoplasm was the first tumor thought to be associated with a herpesvirus (Lucké 1938) and the Lucké tumor herpesvirus (LTV) was subsequently shown to be the etiological agent of the malignancy (Naegele et al. 1974). Viruses which infect eukaryotic cells often have a latent stage in which virions are not detectable (Griffiths 1992). The oncogenic LTV enters such a latent phase at warm temperatures (Zambernard \& McKinnell 1969). We developed a PCR procedure to detect LTV DNA in tumors and other tissues (Carlson et al. 1994a, b, 1995, McKinnell et al. 1995). In the present study, we used the PCR

\footnotetext{
•E-mail: jwilliams@acd tusk.edu
}

procedure to ascertain if the Lucké pronephric tumorderived cell line, PNKT- $4 \mathrm{~B}$, and a normal frog pronephric cell line, WMPA, contain the oncogenic Lucké herpesvirus DNA. We report here that neither the tumorderived cell line nor the normal cell line contains the LTV DNA Hind III restriction fragment JH12.

\section{MATERIALS AND METHODS}

Cell lines. PNKT-4B is a variably aneuploid cell line (Williams et al. 1990) derived from a pronephric renal tumor of Rana pipiens (Tweedell 1978). Cells, grown in modified Leibovitz's L-15 (Leibovitz 1963), supplemented with fetal calf serum and antibiotics, were harvested at confluency and centrifuged to form a pellet. WMPA cells, derived from normal pronephroi (Wong \& 
Tweedell 1974), were similarly grown to confluency and hirvested.

PCR analysis. DNA was isolated from the cell culture pellets by the method of Jackson et al. (1991). Two 22 bp oligonucleotide primers were used to detect the presence of a $1.2 \mathrm{kbp}$ Hind III restriction fragment of LTV DNA, JH12 (Carlson et al. 1995). Between 1 and $4 \mu$ lof template DNA (200 to $400 \mathrm{ng} \mathrm{\mu l}^{-1}$ ) was placed in a total reaction volume of $50 \mu \mathrm{l}: 0.2 \mathrm{mM}$ each of dATP, dCTP, dGTP and dTTP (Gibco/BRL, Grand Island, NY, USA); $1 \mu \mathrm{M}$ of each primer; 1.25 units Taq in Taq polymerase buffer plus $\mathrm{Mg}^{2 *}$ (Boehringer Mannheim, Indianapolis, IN, USA). The reaction was run through 40 cycles ( 1 min at $95^{\circ} \mathrm{C}, 2 \mathrm{~min}$ at $55^{\circ} \mathrm{C}, 3 \mathrm{~min}$ at $72^{\circ} \mathrm{C}$ ) on a Coy Model 60 Tempcycler (Coy Laboratory Products, Ann Arbor, MI, USA). The initial denaturing step was extended to $3 \mathrm{~min}$.

Analysis of PCR products. The PCR reaction products were subjected to electrophoresis on a $1 \%$ agarose gel in $0.5 \times$ Tris-borate-EDTA buffer. The DNA on the gel was transferred to a MagnaNT nylon membrane (Micron Separations, Westboro, MA, USA) for Southern hybridization and probed with the Hind III $1.2 \mathrm{kbp}$ LTV restriction fragment labeled with digoxigenin. The membrane was washed and incubated with antidigoxigenin antibody conjugated with alkaline phosphatase. LumiPhos ${ }^{\mathrm{TM}} 530$ was added to the membrane. Subsequent exposure to Kodak XAR film allowed for visualization at the sites of hybridization (The Genius $^{\text {TM }}$ System, Boehringer Mannheim).

\section{RESULTS}

PNKT-4B and WMPA cells were examined for the presence of the Hind III restriction fragment of LTV DNA by analysis of the PCR products and Southern hybridization. We did not detect the presence of the restriction enzyme fragment in either cell type (Fig. 1).

\section{DISCUSSION}

The PCR procedure used in this study was developed to detect the presence of LTV DNA in tissues lacking a productive viral infection. LTV-infected tissues which do not exhibit a productive infection and therefore lack virions detectable with electron microscopy (Zambernard \& Mckinnell 1969) retain viral DNA. We previously reported the presence of LTV DNA in all spontaneous mesonephric Lucké renal carcinomas (with both productive and latent LTV infections) (Carlson et al. 1994a, b, 1995, McKinnell et al. 1995).

PNKT-4B is a pronephric Lucké tumor-derived cell line which has been maintained in continuous culture for at least $17 \mathrm{yr}$ (Tweedell 1978). Because the primary neoplasm was induced by LTV, it seemed reasonable to inquire if the etiological agent has persisted in the PNKT-4B cell line for this extended period. We report here that LTV DNA was not found by PCR amplification of the Hind III 1.2 kbp fragment in PNKT-4B.

Invasion is an essential step in the cascade of events leading to metastatic cancer. The Lucké renal adenocarcinoma, as expected, is invasive and metastatic as a primary tumor in vivo (McKinnell \& Tarin 1984) and is invasive in vitro (Mareel et al. 1985, McKinnell et al. 1986). It is interesting to note that PNKT-4B retained this competence to invade in vitro (McKinnell et al. 1988). Primary Lucké renal adenocarcinoma cells, as well as normal frog cells, have a well developed typical cytoplasmic microtubule complex (CMTC) at 20 and $28^{\circ} \mathrm{C}$. The CMTC is well organized in normal cells at
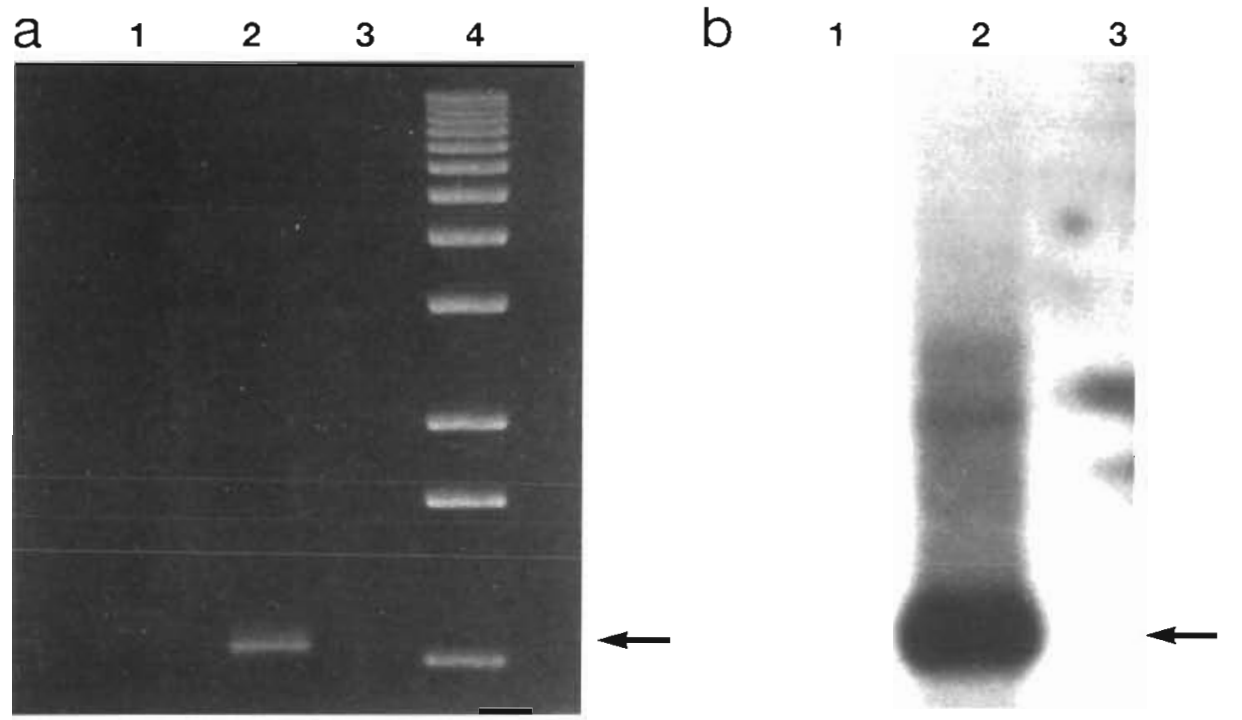

Fig. 1. Agarose gel electrophoresis and Southern hybridization of products resulting from $\mathrm{PCR}$ amplification of a $1.2 \mathrm{kbp}$ Hind III restriction fragment of LTV DNA derived from Rana pipiens kidney cell lines. (a) Agarose gel of PCR products, Lane 1: PNKT$4 B$ (negative for the $1.2 \mathrm{kbp}$ fragment). Lane 2: Positive control (1.2 kbp Hind III fragment). Lane 3: Negative control $\left(\mathrm{H}_{2} \mathrm{O}\right)$. Lane 4: 1 kbp DNA ladder. (b) Southern hybridization of agarose gel. Lane 1. PNKT-4B (negative for the $1.2 \mathrm{kbp}$ fragment). Lane 2: Positive control $\$ 1.2 \mathrm{kbp}$ find III fragment). Lane 3: Negative control $\left(\mathrm{H}_{2} \mathrm{O}\right\}$. Arrows indicate $1.2 \mathrm{kbp}$ 
$7^{\circ} \mathrm{C}$ but it is disorganized in the frog renal adenocarcinoma at that temperature. The CMTC of PNKT-4B is intact at 20 and $28^{\circ} \mathrm{C}$ but is disorganized at $7^{\circ} \mathrm{C}$. Thus, the CMTC of PNKT- $4 \mathrm{~B}$ resembles that of primary Lucké renal carcinoma, not normal frog cells (McKinnell et al. 1984). Current data indicate that sometime since its establishment as an immortal transformed cell line, PNKT-4B has apparently lost at least a fraction of the genome of the etiological agent responsible for transformation, LTV. At present, the nature of the genetic or epigenetic event in the PNKT-4B tumorderived cells, which permits the escape of the etiological agent DNA, but allows for retention of neoplastic characteristics, is not known.

There is, at present, no evidence to indicate that LTV DNA is integrated into the genome of the host frog. The lack of integration may make LTV DNA vulnerable to loss from rapidly replicating cells such as PNKT. $4 \mathrm{~B}$. There is another example of loss of LTV DNA from cells under rapid mitosis. Lucké tumor nuclei, when transplanted into enucleated ova, result in mitotic progeny which undergo significant embryonic differentiation (Lust et al. 1991, McKinnell 1994). Most (31 of 34) embryos produced by tumor nuclear transplantation lack the LTV Hind III $1.2 \mathrm{kbp}$ restriction enzyme fragment (Carlson et al. 1994b). PNKT-4B similarly lacks the JH12 fragment as reported here.

The possibility of LTV DNA integration in the host genome, however, does not eliminate the potential for its loss as a cell cycle, rate dependent, event. It is possible that the replication origin, controlling synthesis of the JH12 fragment, is unable to adapt to the rapid cell cycles in the examples described above. Previous studies (DiBerardino \& Hoffner 1970) have indicated that abnormal nuclear transplant embryos and larvae derived from late stage embryo nuclear donors are associated with chromosome abnormalities that appear to result from a failure of some chromosome regions to adapt to the rapid mitoses that follow nuclear transplantation. Observations of the karyotype of PNKT-4B, which displays significant chromosome rearrangements when compared to both normal frog and tumor karyotypes (Williams et al. 1990, 1993), suggest that alterations in replication patterns may result in immortalization of the cell line. Such alterations may be the mechanism by which JH12 is lost.

We did not expect WMPA cells, derived from normal Rana pipiens embryos, to contain JH12. WMPA met our expectations.

Acknowledgements. This work was supported by Grant 2675BR1 to R.G.M. from the Council for Tobacco Research U.S.A., Inc., Grants SO6GM08091 and G12RRO3059 to J.W.W. III from the National Institutes of Health, and by a grant from the Augustana Research and Artist Fund to D.L.C.
We thank the Minnesota Agricultural Experiment Station for providing funds that enabled Tuskegee University graduate students D.S. and N.M. to work in Saint Paul during the summer of 1995

\section{LITERATURE CITED}

Carlson DL, Sauerbier W, Rollins-Smith LA, McKinnell RG (1994a) The presence of DNA sequences of the Lucké herpesvirus in normal and neoplastic kidney tissue of Rana pipiens. J Comp Pathol 110:349-355

Carlson DL, Sauerbier W, Rollins-Smith LA, McKinnell RG (1994b) Fate of herpesvirus in embryos and tadpoles cloned from Lucké carcinoma nuclei. J Comp Pathol 111: 197-203

Carlson DL, Williams JW III, Rollins-Smith LA, Christ GC, John JC, William.s CS, McKinnell RG (1995) Pronephric carcinoma: chromosomes of cells rescued from apoptosis by an oncogenic herpesvirus detected with a polymerase chain reaction. J Comp Pathol 113:277-286

DiBerardino MA, Hoffner N (1970) Origin of chromosomal abnormalities in nuclear transplants-a reevaluation of nuclear differentiation and nuclear equivalence in amphibians. Dev Biol 23:185-209

Griffiths P (1992) Chronic viral infections. In: McGee JO'D, Isaacsson PG. Wright NA (eds) Oxford textbook of pathology, Vol 1. Oxford University Press, Oxford, p 484-487

Jackson DP, Hayden JD, Quirke P (1991) Extraction of nucleic acid from fresh and archival material. In: McPherson MJ, Quirke P, Taylor GR (eds) PCR: a practical approach. Oxford Unversity Press, Oxford, p 29-50

Leibovitz A (1963) The growth and maintenance of tissue cell cultures in free gas exchange with the atmosphere. Am J Hyg 78:173-180

Lucké B (1938) Carcinoma of the leopard frog: its probable causation by a virus. J Exp Med 68:457-466

Lust JM, Carlson DL, Kowles R, Rollins-Smith LA, Williams JW IIl, McKinnell RG (1991) Allografts of tumor nuclear transplantation cmbryos: differentiation competence. Proc Natl Acad Sci USA 88:6883-6887

Mareel M, Bruncel $R$, Tweedell $K$, Mckinnell $R$, Tarin D (1985) Temperature-dependence of PNKT-4B frog carcinoma cell invasion in vitro. In: Hellmann $K$. Ercles SA. (eds) Treatment of metastasis: problems and prospects. Taylor and Francis, London, p 335-338

McKinnell RG (1994) Reduced oncogenic potential associated with differentiation of the Lucké renal adenocarcinoma. In Vivo $8: 65-70$

McKinnell R, Brunyeel EA, Mareel MM, Tweedell KS, Mekela P (1988) Temperature-dependent malignant invasion in vitro by frog renal carcinoma-derived PNKT-4B cells. Clin Exp Metastasis 6:49-59

McKinnell RG, Carlson DL, Christ CG, John JC (1995) Detection of Lucke tumor herpesvirus DNA sequences in normal and neoplastic tissue obtained from the northern leopard frog, Rana pipiens. In: Zwart P, Matz G (eds) Comptes Rendus Cinquieme international de Pathologie des Reptiles et des Amphibiens. NRG Repro Facility BV, 's-Hertogenbosch, p 13-16

McKinnell RG, De Bruyne G, Mareel MM, Tarin D. Tweedell KS (1984) Cytoplasmic microtubules of normal and tumor cells of the leopard frog: temperature effects. Differentiation 26:231-234

McKinnell R, Mareel MM, Brunyeel EA, Seppanen ED, Mekala PR (1986) Invasion in vitro by explants of Lucké renal carcinomas cocultured with normal tissue is tem- 
perature dependent. Clin Exp Metastasis 4:237-243

McKinnell RG, Tarin D (1984) Temperature-dependent metastasis of the Lucké renal carcinoma and its significance for studies on mechanisms of metastasis. Cancer Metastasis Rev 3:373-386

Naegele RF, Granoff A, Darlington RW (1974) The presence of the Lucké herpesvirus genome in induced tadpole tumors and its oncogenicity: Koch-Henle postulates fulfilled. Proc Natl Acad Sci USA 71:830-834

Tweedell KS (1978) Pronephric tunor cell lines from herpesvirus transformed cells. International Agency for Research on Cancer Scientific Publication 24, 11:609-616

Williams JW III, Carlson DL, Gadson RG, Rollins-Smith L,

Responsible Subject Editor: P. Zwart, Utrecht, The Netherlands
Williams CS, McKinnell RG (1993) Cytogenetic analysis of triploid renal carcinoma in Rana pipiens. Cytogenet Cell Genet 64:18-22

Williams JW III, Smith MD, Carlson DL, Williams CS, Tweedell KS, McKinnell RG (1990) Culture of PNKT-4B cells at invasion permissive and restrictive temperatures. I. Chromosomai analysis. Clin Exp Metastasis 8:267-276

Wong WY, Tweedell KS (1974) Two viruses from the Lucké tumor isolated in a frog pronephric cell line. Proc Soc Exp Biol Med 145:1201-1206

Zambernard J, McKinnell RG (1969) 'Virus-free' renal tumors obtained from prehibernating leopard frogs of known geographic origin. Cancer Res 29:653-657

Manuscript first received: January 27, 1996

Revised version accepted: February 13, 1996 